\title{
Rancang Bangun Sistem Informasi Realisasi Anggaran Kegiatan Berbasiskan Web dan Mobile pada Dishubkominfo Provinsi Sumatera Barat
}

\author{
Husnil Kamil1 , Aisyatul Lathifah $\mathrm{S}^{2}$ \\ 1,2 Jurusan Sistem Informasi, Fakultas Teknologi Informasi, Universitas Andalas \\ (corresponding author) husnil.k@gmail.com
}

\begin{abstract}
Dishubkominfo (Dinas Perhubungan Komunikasi dan Informatika) of West Sumatera Province is a government agency that has the Decentralization authority and Decocentry duty regarding transportation, communications and informatics and also assistance tasks provided by the government. One of the main components of this agency is the activity budget. Activity budgets is one thing that is sensitive and requires good implementation and management. Based on the analysis that has been done, it is found that the system of budget realization of the current system at Dishubkominfo of West Sumatera Province is still not optimal and has many problems such as invalid data and information, data processing that takes long time, and difficulty in accessing information regarding activity budget. Thus, Dishubkominfo need as a system to overcome problems in budget realization. The purpose of this research is for developing web based with mobile access of budget realization information system at Dishubkominfo West Sumatera. This research metodhology adopt the waterfal model of software development lifecycle. This research produce a web based and mobile information system of realization of activity budget based. This information system has been tested by using black box method and has undergone UAT. The test results show the system that has been built in accordance with the Dishubkominfo West Sumatra Province requirements.
\end{abstract}

Keyword- activity budget, information system of realization of activity budget, Dishubkominfo West Sumatera Province, web based, mobile access.

Intisari - Dishubkominfo (Dinas Perhubungan Komunikasi dan Informatika) Provinsi Sumatera Barat merupakan suatu instansi pemerintahan yang bertugas untuk melaksanakan kewenangan Desentralisasi dan tugas Dekosentrasi di bidang Perhubungan, Komunikasi dan Informatika serta tugas pembantuan yang diberikan oleh pemerintah. Salah satu komponen utama pada instansi ini adalah anggaran kegiatan. Anggaran kegiatan termasuk salah satu hal yang bersifat sensitif dan membutuhkan fungsi pelaksanaan dan pengelolaan yang baik. Berdasarkan analisis yang telah dilakukan didapatkan informasi bahwa sistem realisasi anggaran kegiatan yang sedang berjalan pada Dishubkominfo Provinsi Sumatera Barat masih belum optimal dan ditemukan masalah seperti data dan informasi yang tidak valid, proses pengolahan data yang cukup lama, dan sulitnya akses informasi tentang anggaran kegiatan. Untuk itu dibutuhkan sistem yang dapat digunakan untuk mengatasi permasalahan dalam realisasi anggaran Dishubkominfo Provinsi Sumatera Barat. Tujuan penelitian ini yaitu untuk membangun sistem informasi realisasi anggaran kegiatan pada Dishubkominfo Provinsi Sumatera Barat berbasis web dengan akses mobile. Metode penelitian yang digunakan mengadopsi metode pengembangan perangkat lunak waterfall. Dari penelitian ini dihasilkan sebuah aplikasi sistem informasi realisasi anggaran kegiatan berbasis web dan mobile. Aplikasi ini telah diuji dengan metode black box serta telah menjalani UAT. Hasil pengujian menunjukkan aplikasi yang dibangun sesuai dengan kebutuhan Dishubkominfo Provinsi Sumatera Barat.

Kata Kunci- anggaran kegiatan, sistem informasi realisasi anggaran kegiatan, Dishubkominfo Provinsi Sumatera Barat, berbasis web, akses mobile.

\section{PENDAHULUAN}

\section{A. Latar Belakang}

Dinas Perhubungan Komunikasi dan Informatika (Dishubkominfo) Provinsi Sumatera Barat adalah salah satu instansi pemerintahan yang bertugas untuk melaksanakan kewenangan Desentralisasi dan tugas Dekosentrasi di bidang Perhubungan Darat, Laut, Udara, Komunikasi dan Informatika serta tugas pembantuan yang diberikan oleh pemerintah. Dishubkominfo melaksanakan wewenang yang diberikan dalam bentuk program dan kegiatan. Pelaksanaan program dan kegiatan tersebut berkaitan dengan realisasi anggaran. Dishubkominfo memiliki anggaran kegiatan yang telah ditetapkan di dalam Anggaran Pendapatan dan Belanja Daerah [1]. Realisasi anggaran kegiatan memiliki beberapa proses, yaitu proses permohonan izin pelaksanaan kegiatan, pelaksanaan anggaran kegiatan, serta adanya laporan berupa kartu kendali yang menyajikan informasi tentang hubungan antara anggaran, realisasi, dan sisa pagu anggaran (wawancara pribadi, 11 Januari 2016). Proses-proses tersebut haruslah berjalan dengan selaras dan terintegrasi. 
Berdasarkan pengamatan yang dilakukan di Dishubkominfo Provinsi Sumatera Barat, didapatkan informasi bahwa pada sistem realisasi anggaran kegiatan ini ditemukan beberapa masalah. Masalah tersebut antara lain data dan informasi yang tidak valid, proses pengolahan data yang memakan waktu cukup lama, serta sulitnya akses informasi tentang anggaran kegiatan yang disebabkan oleh kantor yang terpisah dan dokumen anggaran yang tidak lengkap. Permasalahan tersebut menyebabkan sistem realisasi anggaran kegiatan berjalan tidak optimal. Selain itu, file dan dokumen yang berkaitan dengan realisasi anggaran seperti kwitansi pembayaran kegiatan tidak tersimpan dan terkomputerisasi dengan baik.

Dewasa ini perkembangan teknologi informasi sudah mampu memberikan bukti nyata dalam peningkatan kinerja di berbagai bidang. Teknologi informasi semakin canggih dan dapat diandalkan untuk mendukung berbagai aktivitas, baik secara organisasi, individu dan juga social [2]. Salah satu bukti nyata lainnya adalah adanya sistem informasi berbasis web maupun mobile yang mampu mengolah dan menyajikan informasi secara cepat, akurat, dan up-to-date. Hal tersebut juga didukung oleh perkembangan penggunaan smartphone yang menjadi tren saat ini. Akses sumber informasi bukan menjadi masalah yang susah lagi seperti dulu [3]. Sistem informasi berbasis web dan mobile memungkinkan pengguna untuk dapat mengakses informasi secara realtime. Perkembangan ini sangatlah membantu dalam menyajikan informasi secara cepat dan efisien dengan pengaksesan internet melalui perangkat mobile. Penggunaan sistem informasi dengan akses mobile dapat memudahkan stakeholder Dishubkominfo Provinsi Sumatera Barat untuk mengakses data anggaran, melakukan persetujuan dan pengesahan dokumen kegiatan, serta dapat melakukan cek status dokumen kegiatan. Meski perangkat mobile merupakan small device dengan layar penyajian yang terbatas, tetapi penyajian informasi tidak kalah optimal layaknya informasi yang diakses dari personal computer [4]. Sistem informasi realisasi anggaran kegiatan berbasis web dengan akses mobile ini diharapkan dapat mengoptimalkan proses realisasi anggaran kegiatan yang menjadi salah satu komponen utama pada instansi ini. Maka dari itu akan dilakukan penelitian yang berjudul "Rancang Bangun Sistem Informasi Realisasi Anggaran Kegiatan Berbasiskan Web dan Mobile pada Dinas Perhubungan Komunikasi dan Informatika Provinsi Sumatera Barat".

\section{A. Realisasi Anggaran Kegiatan}

\section{TINJAUAN PUSTAKA}

Anggaran merupakan pedoman tindakan yang akan dilaksanakan pemerintah meliputi rencana pendapatan, belanja, transfer, dan pembiayaan yang diukur dalam satuan rupiah, yang disusun menurut klasifikasi tertentu secara sistematis untuk satu periode. Anggaran merupakan pernyataan kuantitatif dari perencanaan badan pemerintah yang dinyatakan baik dalam bentuk fisik maupun keuangan atau keduanya. Dari pengertian tersebut dapat disimpulkan bahwa anggaran merupakan suatu rencana atau pedoman pemerintah yang disusun secara sistematis dan direncanakan secara kuantitatif untuk jangka waktu tertentu dan umumnya dinyatakan dalam satuan uang, tetapi dapat juga dinyatakan dalam satuan barang [5].

Realisasi adalah tindakan yang nyata atau adanya pergerakan atau perubahan dari rencana yang sudah dibuat atau dikerjakan. Realisasi anggaran kegiatan merupakan proses perencanaan, pendistribusian, dan pelaporan penggunaan anggaran terhadap suatu kegiatan di Dinas Perhubungan Komunikasi dan Informatika Provinsi Sumatera Barat. Berdasarkan hasil wawancara dengan bendahara pengeluaran Dishubkominfo Provinsi Sumatera Barat, realisasi anggaran kegiatan memiliki tiga sub sistem, (wawancara pribadi, 11 Januari 2016) yaitu

1. Permohonan Izin Pelaksanaan Kegiatan

Permohonan izin pelaksanaan kegiatan merupakan tahap pra pelaksanaan anggaran kegiatan. Pada tahap ini melibatkan Pejabat Teknis Pelaksana Kegiatan (PPTK), Kuasa Pengguna Anggaran (KPA), dan sub bagian keuangan. Tahapan ini bertujuan untuk permohonan persetujuan dengan mengajukan telaahan staf yang berpedoman kepada anggaran kegiatan.

2. Pelaksanaan Anggaran Kegiatan

Pelaksanaan anggaran kegiatan merupakan tahap pelaksanaan kegiatan yang telah disetujui dan dianggarkan. Pada tahap ini melibatkan Pejabat Teknis Pelaksana Kegiatan (PPTK), Kuasa Pengguna Anggaran (KPA), dan bendahara pengeluaran. Tahapan ini bertujuan untuk melaksanakan kegiatan yang telah disetujui sekaligus pendistribusian anggaran dana untuk kegiatan tersebut.

3. Kartu Kendali Kegiatan

Kartu kendali kegiatan merupakan bagian dari sebuah Laporan Realisasi Anggaran (LRA). Realisasi anggaran adalah menyajikan ikhtisar sumber, alokasi dan pemakaian sumber dana ekonomi yang dikelola oleh pemerintahan daerah, yang menggambarkan perbandingan antara anggaran dan realisasinya dalam satu periode pelaporan (Nur Afiah 2001, p.13). Kartu kendali kegiatan ini dibuat menggunakan fungsi dari Microsoft Excel yang menyajikan data kegiatan dan perbandingan antara anggaran dengan realisasinya dalam satu periode pelaporan. Pada tahap ini pihak yang terlibat adalah Pejabat Teknis Pelaksana Kegiatan (PPTK), Kuasa Pengguna Anggaran (KPA), dan Sub Bagian Keuangan. Kartu kendali kegiatan ini berfungsi untuk menyajikan informasi tentang penggunaan anggaran, persentase keuangan, dan sisa pagu anggaran kegiatan per bulan. 


\section{B. Penelitian Terkait}

Terdapat beberapa penelitian yang terkait dengan penelitian yang dilakukan. Pertama, penelitian yang dilakukan oleh I Gusti Ngurah Gandhi Prabawa pada tahun 2013 yang berjudul Rancang Bangun Aplikasi Alokasi dan Realisasi Anggaran Berbasis Web pada PT Telekomunikasi Indonesia, TBK Surabaya. Perancangan aplikasi ini bertujuan untuk dapat membantu mempercepat dalam mengawasi anggaran di bawah unit IS SSM di setiap area PT Telkom. Aplikasi ini meliputi proses pemeliharaan akun, pemeliharaan cos center area, alokasi anggaran, realisasi anggaran dan laporan bulanan. Berdasarkan hasil uji coba aplikasi, dapat disimpulkan bahwa aplikasi ini berjalan dengan baik dan menghasilkan laporan bulanan yang berisi total anggaran, total realisasi dan total sisa anggaran. Aplikasi ini juga mempermudah pihak-pihak yang berkepentingan untuk mendapatkan informasi laporan bulanan dengan lebih cepat dan akurat kepada general manager dan manager [6]. Penelitian kedua yaitu penelitan yang dilakukan oleh Moh. Rizal Hidayat, Arifin Puji Widodo, dan Ayuningtyas pada tahun 2014 yang berjudul Rancang Bangun Aplikasi Analisis Laporan Realisasi Anggaran Pembangunan Gedung Mengacu pada Standar Nasional Indonesia pada CV. Citra Mandiri Solution. Penelitian ini menghasilkan aplikasi analisis laporan realisasi anggaran pembangunan gedung yang mengacu pada SNI dan perlengkapannya (dokumen spesifikasi kebutuhan perangkat lunak, desain dan testing). Sistem ini dapat membuat rancangan biaya yang mengacu pada SNI dan menjalankan proses serta membuat laporan tentang analisis perbandingan antara LRA dengan RAB, RAB dengan SNI, dan LRA dengan SNI. Sehingga dari semua informasi yang telah dihasilkan oleh aplikasi analisis laporan realisasi anggaran tersebut bisa digunakan sebagai pendukung keputusan dalam perencanaan proyek selanjutnya [7]. Penelitian ketiga yaitu penelitian yang dilakukan oleh Eka Jufriani pada tahun 2012 yang berjudul Perancangan Sistem Informasi Akuntansi Realisasi Anggaran pada Dinas PU Kabupaten Barito Timur dengan Menggunakan Microsoft Visual Basic 6.0 dan SQL Server 2000 Berbasis Client Server. Hasil penelitian ini adalah sebuah perancangan sistem informasi akuntansi realisasi anggaran dengan menggunakan kelengkapan sistem diagram konteks, data flow diagram (DFD), entity relationship diagram (ERD), dan flowchart yang berupa input dari data-data transaksi pencairan dana dan pemakaian dana, proses yang terdiri dari jurnal umum dan buku besar, sedangkan outputnya berupa laporan realisasi anggaran[8]. Aplikasi pada penelitian ini menggunakan database SQL Server 2000 dan software Visual Basic.

Dari penjelasan ketiga penelitian di atas, disimpulkan bahwa belum ada penelitian tentang pembangunan sistem informasi realisasi anggaran kegiatan yang memanfaatkan aplikasi mobile untuk mempermudah akses informasi. Aplikasi yang dibuat pada penelitian sebelumnya sebagian besar berbasiskan website dan desktop.

\section{Metode Penelitian}

Metode penelitian yang digunakan dalam penelitian ini mengadopsi metode pengembangan perangkat lunak waterfall. Hal ini dikarenakan penelitian yang dilakukan berupa pengembangan perangkat lunak. Metode pengembangan waterfall dapat dilihat pada Gambar 1. Tahapan penelitian yang dilakukan adalah sebagai berikut:

1. Analysis (Analisis)

Analisis sistem dilakukan untuk mengidentifikasikan dan mengevaluasi permasalahan-permasalahan, hambatanhambatan yang terjadi dan kebutuhan-kebutuhan yang diharapkan sehingga dapat diusulkan perbaikan-perbaikan. Pada tahapan ini dilakukan analisis terhadap sistem yang sedang berjalan. Data untuk analisis didapatkan melalui 3 cara yaitu wawancara, observasi dan analisis dokumen. Berdasarkan hasil analisis sistem yang sedang berjalan digambarkan usulan sistem yang baru dengan menggunakan tools BPMN. Setelah analisis sistem selesai dilakukan maka dilanjutkan ke tahap desain sistem.

2. Design (Desain)

Pada tahapan ini dilakukan perancangan sistem yang terdiri dari perancangan database, arsitektur perangkat lunak, dan perancangan antarmuka dengan menggunakan tools UML dan ERD. Tahap ini mentranslasi kebutuhan perangkat lunak dari tahap analisis kebutuhan ke representasi desain agar dapat diimplementasikan menjadi program pada tahap selanjutnya. Setelah tahap desain sistem selesai dilakukan, pengembangan dilanjutkan ke tahap pengkodean program.

3. Coding (Pengkodean)

Desain harus ditranslasikan ke dalam program perangkat lunak. Hasil dari tahap ini adalah program komputer sesuai dengan desain yang telah dibuat pada tahap desain.

4. Testing (Pengujian)

Tahap pengujian fokus pada perangkat lunak secara dari segi logic dan fungsional dan memastikan bahwa semua bagian sudah diuji. Hal ini dilakukan untuk meminimalisir kesalahan (error) dan memastikan keluaran yang dihasilkan sesuai yang diinginkan [9]. Dalam penelitian ini pengujian sistem dilakukan dengan menggunakan pengujian Black-box. Pengujian Black-box berfokus pada persyaratan fungsional perangkat lunak. Dengan demikian, pengujian metode ini memungkinkan perekayasa perangkat lunak mendapatkan serangkaian kondisi input yang sepenuhnya menggunakan samua persyaratan fungsional untuk suatu program. 


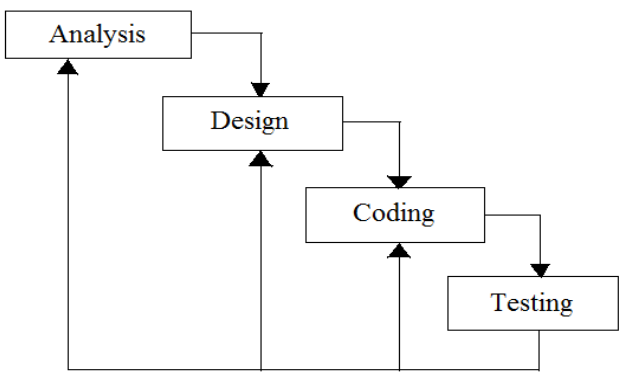

Gambar 1. Metode Pengembangan Waterfall

\section{Analisis dan Perancangan Sistem}

Tahapan pertama yang dilakukan dalam penelitian ini adalah analisis sistem yang dibangun dan dilanjutkan dengan merancang sistem yang dibangun. Berikut ini adalah penjelasan terkait tahapan analisis dan desain dalam penelitian ini.

\section{A. Analisis Sistem}

\section{1) Analisa Proses Bisnis}

Analisis sistem dilakukan untuk menggali kebutuhan terhadap sistem informasi realisasi anggaran kegiatan. Analisis dilakukan dengan memodelkan proses bisnis yang sedang berjalan dan mengusulkan proses bisnis baru yang dioptimalkan dengan menggunakan sistem yang dibangun. Proses bisnis tersebut dimodelkan dengan menggunakan BPMN (Business Process Model Notation). Terdapat 3 komponen kegiatan dalam realisasi anggaran di Dishubkominfo Provinsi Sumatera Barat. Setiap komponen perlu dianalisis dan dibuatkan proses yang baru. Gambar 2 merupakan BPMN untuk permohonan izin pelaksanaan kegiatan.

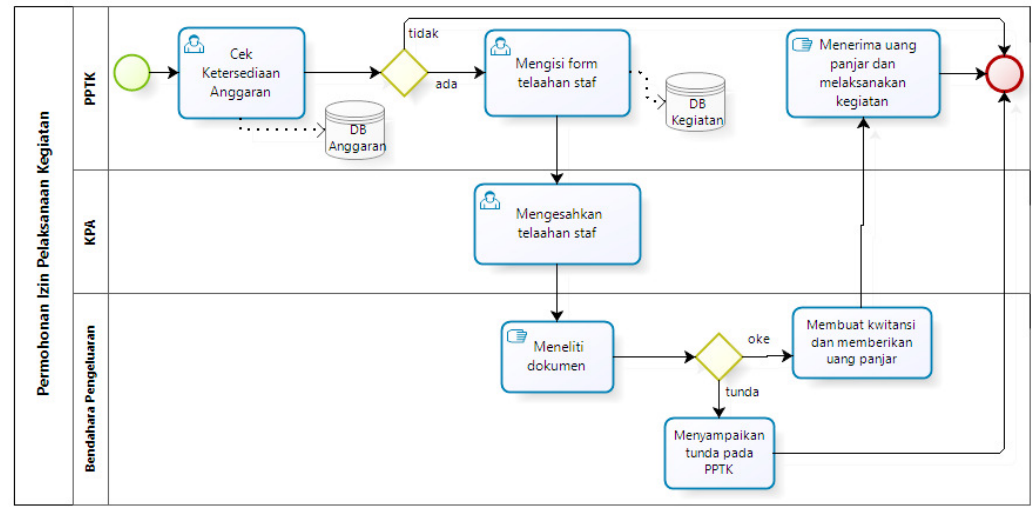

Gambar 2. BPMN Permohonan Izin Pelaksanaan Kegiatan

Deskripsi proses permohonan izin pelaksanaan kegiatan:

1. PPTK melakukan cek ketersediaan anggaran. Jika anggaran tidak tersedia, maka proses akan berhenti. Jika anggaran tersedia, maka PPTK mengisi form telaahan staf sebagai dasar untuk permintaan uang panjar secara online. Kemudian sistem akan mengirimkan telaahan untuk disahkan oleh KPA

2. KPA mengesahkan telaahan staf, telaahan dan dokumen permintaan panjar yang telah didisposisi tersebut akan dikirim oleh sistem kepada bendahara pengeluaran

3. Bendahara pengeluaran meneliti telaahan staf dan dokumen permintaan panjar. Jika dokumen tidak lengkap, maka bendahara pengeluaran menyampaikan tunda pada PPTK. Jika telaahan staf oke, bendahara pengeluaran membuat kwitansi panjar dan memberikan uang panjar kegiatan kepada PPTK

4. PPTK menerima uang panjar dan melaksanakan kegiatan

\section{2) Kebutuhan Fungsional Sistem}


Berdasarkan analisis alur proses sistem informasi realisasi anggaran kegiatan yang diusulkan maka dapat dirumuskan beberapa kebutuhan fungsional sistem yaitu:

1. Admin keuangan menginput dan memperbarui data anggaran kegiatan

2. PPTK dapat mengisi form telaahan staf dan menginputkan data kelengkapan kegiatan secara online

3. KPA dan bendahara pengeluaran dapat melakukan persetujuan atau konfirmasi dokumen kegiatan melalui akses web maupun mobile

4. PPTK dapat melakukan cek status telaahan staf melalui web dan mobile

5. PPTK dapat melakukan print out kartu kendali kegiatan berdasarkan periode realisasi anggaran

6. Semua user dapat melihat kartu kendali dan laporan realisasi anggaran kegiatan

Fungsional diatas dijabarkan menjadi 19 fungsional yang berelasi dengan pengguna sistem (aktor). Terdapat empat aktor yang menggunakan sistem, yaitu admin keuangan, pejabat pelaksana teknis kegiatan (PPTK), kuasa pengguna anggaran (KPA), dan bendahara pengeluaran. Setiap aktor diharuskan untuk login sebelum menggunakan sistem. Use case diagram yang dirancang dapat dilihat pada Gambar 3.

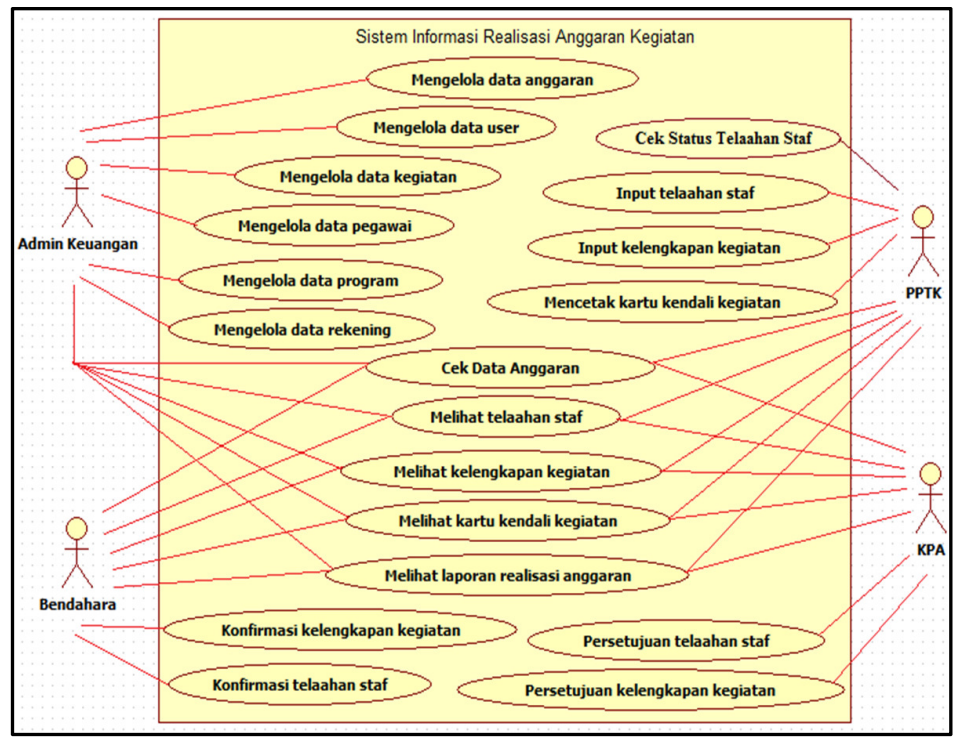

Gambar 3. Use case diagram sistem informasi realisasi anggaran kegiatan

Setiap use case yang ada dalam use case diagram perlu dianalisa lebih lanjut. Analisa terhadap use case menghasilkan skenario use case dan sequence diagram. Skenario use case ini menjelaskan langkah-langkah user dalam menggunakan fungsional yang ada pada sistem. Tabel 1 merupakan contoh skenario use case cek data anggaran. Skenario use case cek data anggaran merupakan alur proses yang harus dilakukan user untuk melihat data anggaran dari suatu kegiatan. Berikut merupakan skenario cek data anggaran:

Tabel 1. Skenario Utama Use Case Cek Data Anggaran

\begin{tabular}{|c|c|c|}
\hline Aktor & \multicolumn{2}{|c|}{ : Admin/PPTK/KPA/Bendahara Pengeluaran } \\
\hline Kondisi awal & \multicolumn{2}{|c|}{ : User telah login } \\
\hline Kondisi akhir & \multicolumn{2}{|c|}{ : Sistem menampikan halaman data anggaran } \\
\hline \multicolumn{2}{|r|}{ Aksi } & Reaksi \\
\hline \multicolumn{3}{|c|}{$\begin{array}{l}\text { 1. PPTK/KPA/Bendahara Pengeluaran membuka } \\
\text { menu "Anggaran" }\end{array}$} \\
\hline & & 2. Sistem menampilkan pilihan data anggaran \\
\hline \multicolumn{3}{|c|}{$\begin{array}{l}\text { 3. PPTK/KPA/Bendahara Pengeluaran memilih } \\
\text { nama kegiatan dan menekan tombol "Lihat" }\end{array}$} \\
\hline & & 4. Sistem memanggil data anggaran kegiatan \\
\hline & & $\begin{array}{l}\text { 5. Sistem menampilkan halaman data anggaran } \\
\text { kegiatan }\end{array}$ \\
\hline
\end{tabular}


Sequence diagram ini dibuat berdasarkan hasil analisis use case diagram, dan kemudian dikembangkan sampai dengan proses terkecil yang ada pada setiap use case. Sequence diagram system ini dapat dilihat pada Gambar 4 .

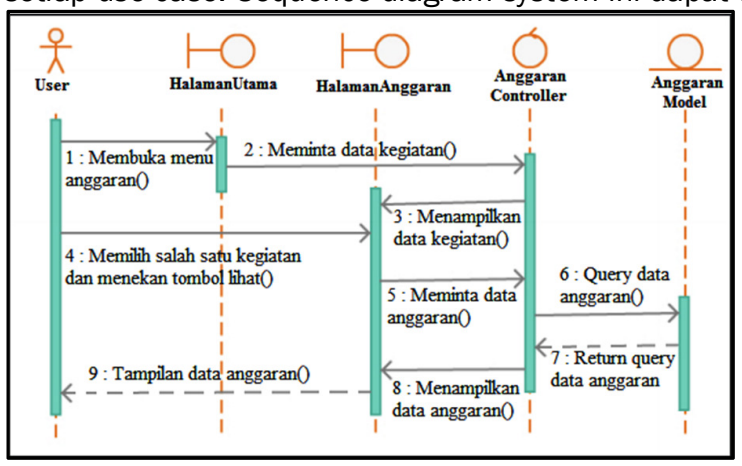

Gambar 4. Sequence diagram cek data anggaran

\section{B. Perancangan Sistem}

Pada tahapan perancangan dilakukan kegiatan merancang arsitektur aplikasi, merancang program dalam bentuk class diagram, rancangan data (ERD) dan rancangan antarmuka pengguna.

\section{1) Arsitektur Aplikasi}

Dalam perancangan dan pembangunan aplikasi sistem informasi realisasi anggaran kegiatan ini digunakan arsitektur aplikasi MVC (Model View Controller) dengan metode OOP (Object Oriented Programming) menggunakan framework Laravel untuk perancangan aplikasi web dan tool App Inventor 2 untuk pengembangan mobile. Arsitektur ini memisahkan antara data (model), tampilan antar muka (view), dan cara pemanggilan keduanya dengan menggunakan controller. Ketika user melakukan permintaan terhadap sistem, routing mengidentifikasi controller dan method apa yang akan digunakan untuk menangani permintaan tersebut. Kemudian controller memanggil data ke model dan model akan mengambil data yang sesuai dari database. Data yang telah diambil dari database ditampilkan oleh controller ke view untuk dapat dilihat oleh user.

Pengembangan aplikasi mobile dengan tool App Inventor 2 terbagi atas dua komponen, yaitu komponen designer dan blocks. Saat user melakukan permintaan terhadap sistem, kode block dijalankan dan melakukan akses ke aplikasi web melalui routing. Routing mengidentifikasi controller dan method yang digunakan dan memanggil data melalui model. Setelah data dipanggil, controller mengirim data JSON yang selanjutnya diterjemahkan oleh komponen block untuk ditampilkan pada halaman user. Mengenai gambaran arsitektur aplikasi sistem ini dapat dilihat pada Gambar 5 .

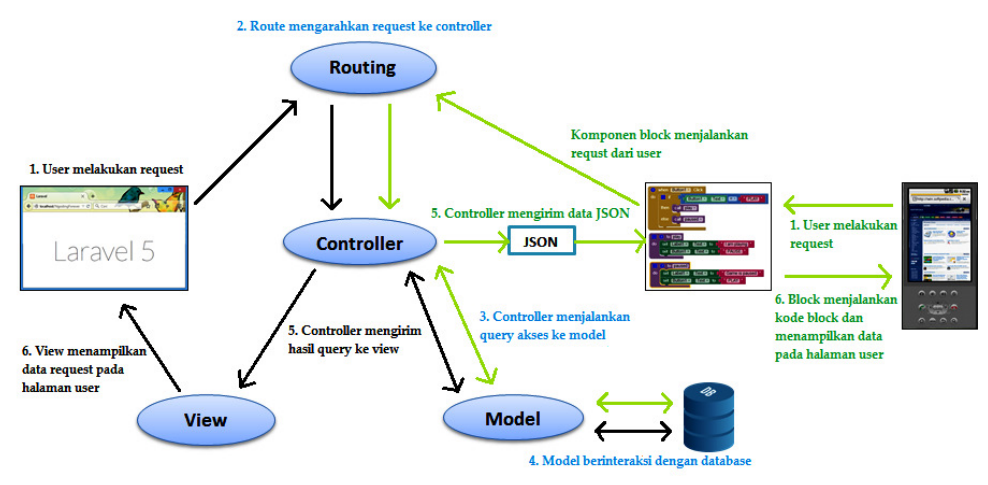

Gambar 5. Arsitektur Aplikasi

Keterangan :

Alur sistem pada aplikasi mobile

Alur sistem pada aplikasi web

2) Class Diagram

Class diagram merupakan gambaran mengenai struktur kelas-kelas dari suatu sistem dan merupakan salah satu diagram yang banyak dipakai. Dengan adanya class diagram diharapkan pembangun sistem dapat terbantu dalam membangun sistem pada tahapan implementasi. Pada class diagram terdapat view, model dan controller. Pada kelas 
juga dipaparkan atribut dari masing-masing kelas beserta fungsi-fungsi yang terkandung didalamnya. Fungsi yang ada pada masing-masing kelas memiliki tugas tersendiri sesuai dengan kebutuhan sistem. Sistem informasi realisasi anggaran ini dibangun dengan menggunakan framework, sehingga rancangan class yang digunakan dalam aplikasi harus mengikuti aturan framework yang digunakan.

\section{3) Perancangan Database}

Perancangan database dimulai dengan menyusun struktur database berdasarkan entitas yang digunakan dan hubungannya dengan entitas-entitas yang lain. Entitas beserta hubungannya tersebut digambarkan dalam sebuah ERD (Entity Relational diagram) yang merepresentasikan model data pada sistem. Tabel-tabel tersebut terdiri dari tabel master dan tabel transaksi yang memiliki relasi satu sama lain. Pada perancangan database ini terdapat empat tabel master, yaitu tabel bidang, pegawai, rekening, dan jenis pembayaran, sedangkan tabel-tabel yang merupakan tabel transaksi adalah tabel user, program, kegiatan, anggaran, telaahan_staf, dan kelengkapan_kegiatan. Untuk lebih jelasnya rancangan ERD dari sistem ini dapat dilihat pada Gambar 6.

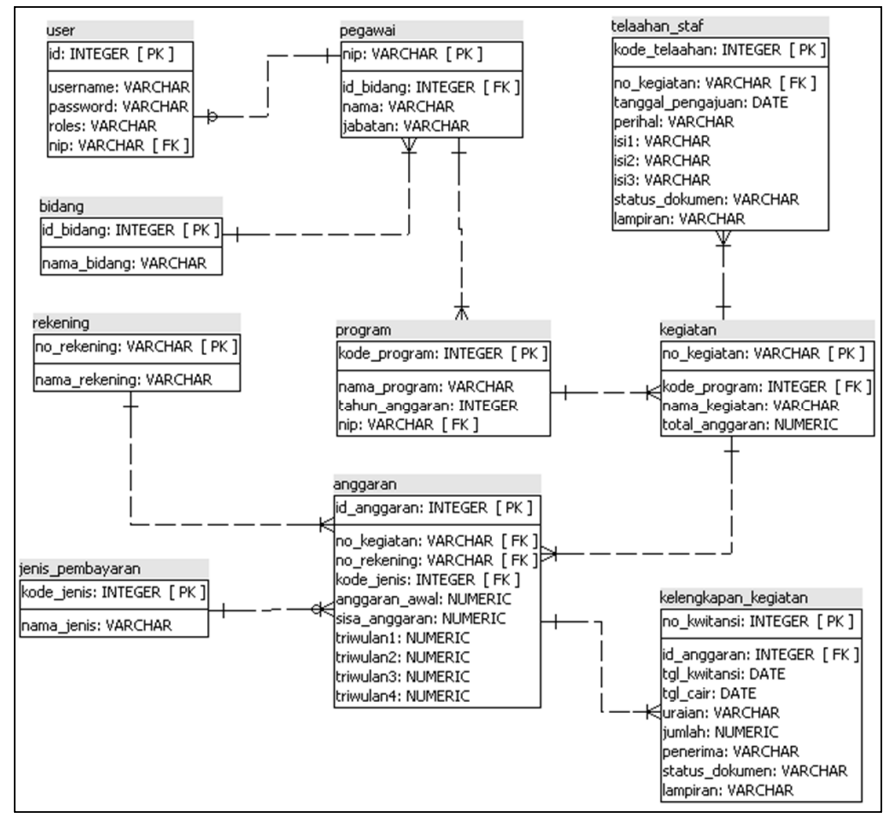

Gambar 6. Entity Relational Diagram (ERD) Sistem Informasi Realisasi Anggaran Kegiatan

\section{4) Perancangan Antarmuka Pengguna}

Rancangan lainnya yang perlu ditentukan adalah rancangan antarmuka pengguna. Rancangan ini memberikan gambaran tampilan aplikasi yang digunakan oleh pengguna. Tampilan aplikasi yang dirancang ada 2 jenis yaitu aplikasi web dan aplikasi mobile. Tampilan antarmuka pengguna untuk aplikasi web dapat dilihat pada Gambar 7 dan Gambar 8. Sedangkan tampilan antarmuka pengguna untuk aplikasi mobile dapat dilihat pada Gambar 9 dan Gambar 10.

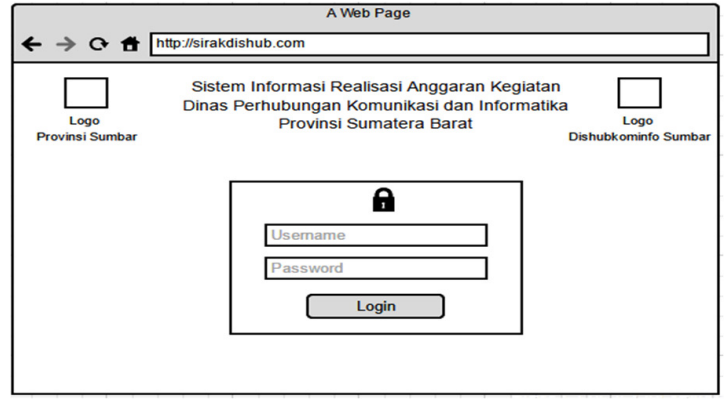

Gambar 7. Rancangan antarmuka pengguna untuk halaman login 


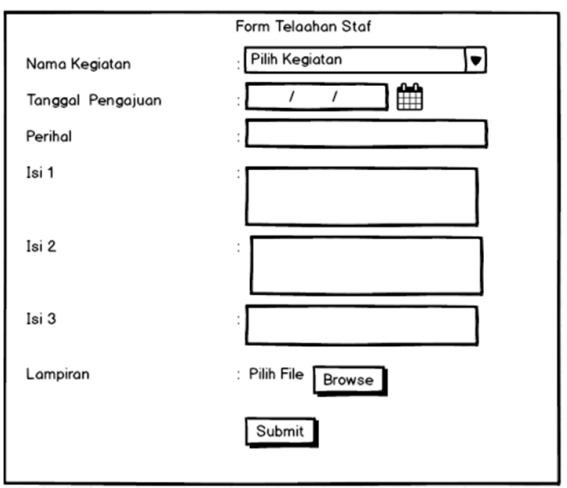

Gambar 8. Perancangan antarmuka pengguna form telaahan staf

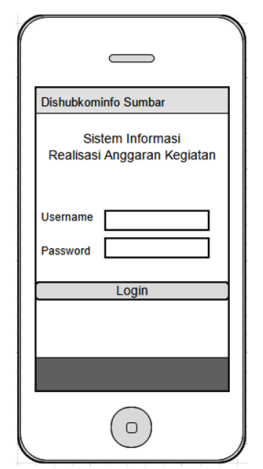

Gambar 9. Rancangan Antarmuka pengguna untuk login pada aplikasi mobile

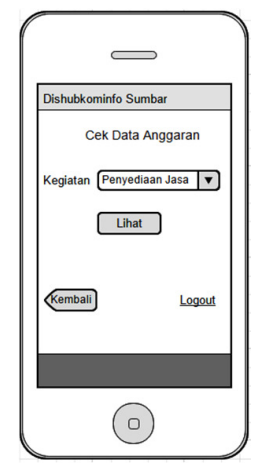

Gambar 10. Rancangan antarmuka pengguna halaman cek anggaran pada aplikasi mobile

\section{IMPLEMENTASI DAN PENGUJIAN SISTEM}

\section{A. Implementasi Sistem}

Tahapan selanjutnya adalah mengimplementasi rancangan sistem dalam bentuk sistem siap pakai. Implementasi sistem ini menggunakan bahasa pemrograman PHP (Hypertext Preprocessor) dan Framework Laravel. Framework Laravel yang digunakan adalah Laravel versi 5.2, sedangkan web server yang digunakan adalah web server apache XAMPP versi 5.6.12. Web server berfungsi untuk menjalankan bahasa pemrograman PHP di browser dan menampilkan data-data yang dipanggil dari database di browser. Database yang digunakan sebagai tempat penyimpanan data dalam implementasi sistem ini adalah database MySQL. Untuk implementasi aplikasi mobile, digunakan tools App Inventor 2 versi 2.39 sebagai perangkat untuk melakukan penyusunan kode program. Aplikasi ini dipilih karena mempunyai beberapa keunggulan 
dibandingkan aplikasi pemrograman mobile sejenisnya, di antaranya adalah lebih ringan, responsive, dan pengkodean dengan visual block programming.

1) Implementasi Antar Muka Aplikasi Web

Aplikasi web yang dibangun dapat diakses oleh user dengan menggunakan web browser. Pada bagian url, user memasukkan alamat domain http://sirakdishubsumbar.esy.es. Halaman awal aplikasi web dapat dilihat pada Gambar 11. Akses sebagai super user pada aplikasi web ini dipegang oleh seorang admin. Admin memiliki wewenang dalam mengelola data master dan data realisasi anggaran. Tampilan halaman admin dapat dilihat pada Gambar 12.

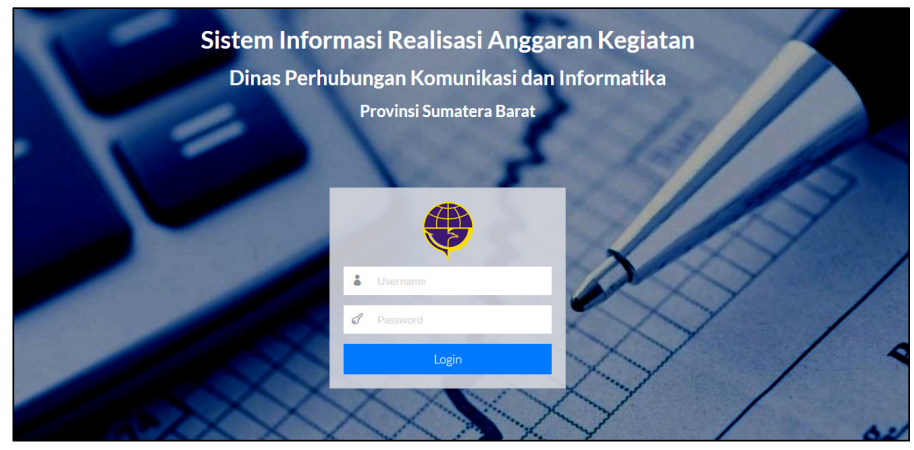

Gambar 11. Tampilan halaman login

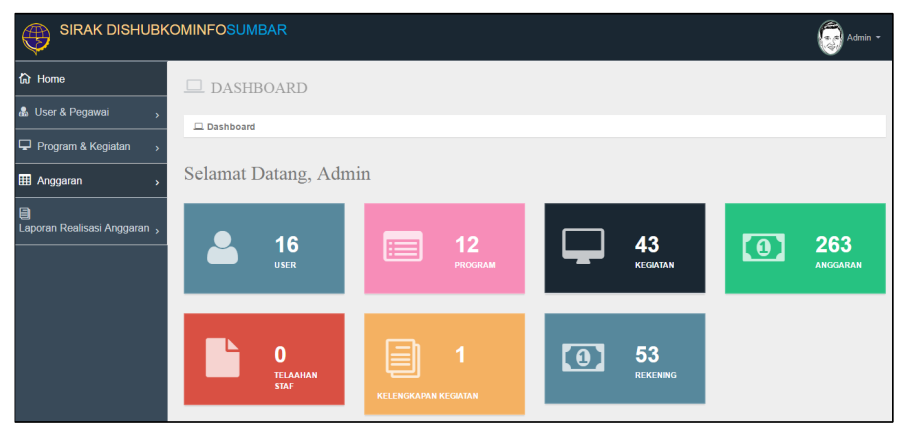

Gambar 12. Tampilan halaman admin

2) Implementasi Antar Muka Aplikasi Mobile

Aplikasi mobile merupakan salah satu hasil implementasi sistem informasi realisasi anggaran kegiatan pada Dishubkominfo Sumbar yang khusus digunakan oleh user dengan hak akses sebagai PPTK, KPA, dan bendahara pengeluaran. Tampilan aplikasi mobile hasil implementasi rancangan sistem dapat dilihat pada Gambar 14 dan Gambar 14.

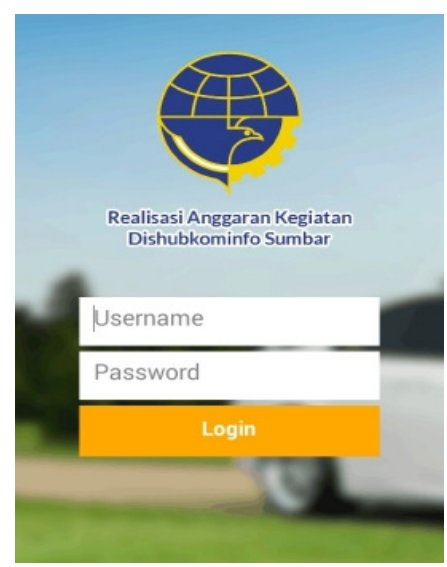

Gambar 14. Halaman login aplikasi mobile

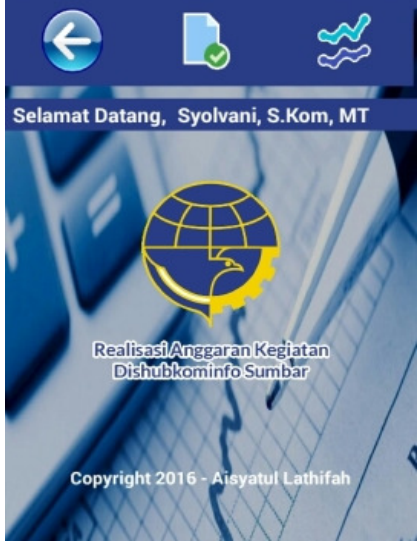

Gambar 14. Halaman utama aplikasi 


\section{B. Pengujian Sistem}

Pada tahapan ini dilakukan pengujian pada semua bagian aplikasi yang telah dibangun. Proses ini dilakukan agar aplikasi yang dibangun berjalan sesuai dengan perancangan sistem. Pengujian ini dilakukan dengan menggunakan metode black box testing, yaitu metode pengujian yang berfokus pada pemeriksaan ketersediaan fungsional yang sudah dirancang pada aplikasi. Tabel 2 menunjukkan hasil pengujian fungsional login. Seluruh fungsional yang telah didefinisikan pada tahapan analisis diuji dengan menggunakan metode yang sama. Hasil pengujian menunjukkan sistem yang dibuat telah sesuai dengan kebutuhan yang ditentukan pada tahapan analisis.

Tabel 2. Pengujian Login

\begin{tabular}{|l|l|}
\hline \multicolumn{2}{|l|}{ Kasus dan Hasil Uji (Benar) } \\
\hline Data masukan & Username : mardiwan Password : mardiwan \\
\hline Yang diharapkan & Login berhasil, masuk ke halaman admin \\
\hline Pengamatan & Dapat mengisi data login sesuai yang diharapkan \\
\hline Hasil & Sesuai harapan \\
\hline
\end{tabular}

\begin{tabular}{|l|l|}
\hline Kasus dan Hasil Uji (Alternatif) \\
\hline Data masukan & Username : mardiwan Password : admin \\
\hline Yang diharapkan & Login gagal dan muncul notifikasi kesalahan \\
\hline Pengamatan & User tidak bisa masuk ke system \\
\hline Hasil & Sesuai harapan \\
\hline
\end{tabular}

\section{KESIMPULAN}

Aplikasi sistem informasi realisasi anggaran kegiatan berbasis web dan mobile pada Dinas Perhubungan Komunikasi dan Informatika Provinsi Sumatera Barat telah berhasil dibangun. Pengembangan sistem informasi ini dilakukan dengan menggunakan metode waterfall yang terdiri dari tahapan analysis, design, coding, dan testing. Terdapat tujuh kebutuhan fungsional utama dan 4 aktor, yaitu admin keuangan, PPTK, KPA, dan bendahara pengeluaran yang didapatkan dari analisis BPMN. Fungsional utama dijabarkan menjadi sembilan belas fungsional yang terdiri delapan belas fungsional pada aplikasi web dan empat fungsional pada aplikasi mobile. Aplikasi mobile hanya digunakan oleh 3 aktor, yaitu aktor PPTK, KPA, dan bendahara pengeluaran dikarenakan ke-3 aktor tersebut membutuhkan informasi dan tindakan yang cepat. Aplikasi web dibangun dengan menggunakan framework Laravel versi 5.2 untuk mempercepat proses pengembangan, sedangkan aplikasi mobile dibangun menggunakan aplikasi App Inventor. Pengujian aplikasi dilakukan dengan menggunakan metode black box dengan fokus pengujian yang terdiri dari empat belas item uji, yaitu sebelas item uji untuk aplikasi web dan empat item uji untuk aplikasi mobile. Dari hasil pengujian diperoleh kesimpulan bahwa ketersediaan fungsional pada aplikasi sudah berjalan sesuai dengan kebutuhan dan perancangan pada tahap awal.

\section{UCAPAN TERIMA KASIH}

Ucapan terima kasih penulis diberikan kepada Tuhan Yang Maha Esa dan Bapak Mardiwan, SE, M.ClO selaku staf subag keuangan dan IT Dishubkominfo Sumatera Barat dan seluruh pihak yang telah membantu yang tidak dapat penulis sebutkan satu persatu.

\section{REFERENSI}

[1] Riduansyah, M. 2003. Kontribusi pajak daerah dan retribusi daerah Terhadap pendapatan asli daerah (PAD) dan anggaran Pendapatan dan belanja daerah (APBD) guna mendukung Pelaksanaan Otonomi Daerah (Studi Kasus Pemerintah Daerah Kota Bogor). Makara, Sosial Humaniora, 7(2).

[2] Bukit, Ernita. 2011.Penerapan E-Business System di Perusahaan Tupperware. Institut Pertanian Bogor.

[3] Wijaya, I. W. G. S. 2012. Penerapan Web Service pada Aplikasi Sistem Akademik pada Platform Sistem Operasi Mobile Android. Teknik Informatika, STIKOM PGRI Banyuwangi. Banyuwangi.

[4] Afrina, M., \& Ibrahim, A. 2014. Pengembangan Model Sistem Informasi Perpustakaan dengan Teknologi Informasi Berbasis Wireless Application Protocol (WAP) Pada Universitas Sriwijaya. Jurnal Sistem Informasi, 4(1).

[5] Harun. 2008. Reformasi Akuntansi dan Manajemen Sektor Publik di Indonesia. Jakarta: Salemba Empat.

[6] Prabawa, I., 2013. LKP: Rancang Bangun Aplikasi Alokasi dan Realisasi Anggaran Berbasis Web Pada PT. Telekomunikasi Indonesia, Tbk Surabaya, STIKOM Surabaya.

[7] Hidayat, M.R., Widodo, A.P. and Tyas, A.N., 2014. Rancang Bangun Aplikasi Analisis Laporan Realisasi Anggaran Pembangunan Gedung mengacu Pada Standar Nasional Indonesia (Studi Kasus: CV. Citra Mandiri Solution). Jurnal JSIKA, 3(1), pp.175-180.

[8] Jufriani, Eka (2013) Perancangan Sistem Informasi Akuntansi Realisasi Anggaran Pada Dinas PU Kabupaten Barito Timur Dengan Menggunakan Microsoft Visual Basic 6.0 Dan SQL Server 2000 Berbasis Client Server. UNIKOM

[9] Rosa, A. S., \& Shalahuddin, M. 2011. Modul Pembelajaran Rekayasa Perangkat Lunak (Terstruktur dan Berorientasi Objek). Bandung: Modula. 